\title{
Hospitalitas pemimpin Dalam Menghadapi kasus Teroris
}

\author{
Markus Pallio’ \\ Institut Agama Kristen Negeri Toraja \\ Mpallio172@gmai.com
}

\begin{abstract}
Abtract
Terrorism is a very serious problem and cannot be underestimated because terrorists are a threat to every citizen because they can cause danger, world discomfort and even because the actions of these terrorists are very detrimental to society. Terrorism is a very extraordinary crime and threatens many lives, so in anticipating the existence of terror from terrorists in an area, the government must also be extra extraordinary in responding to and dealing with terrorist problems.
\end{abstract}

In our country, of course, the leadership hospitality shown by the government can be seen from how the movements are carried out both in terms of punishment for terrorist actors and also the readiness of authorized officers such as the TNI and POLRI.

\section{abstrak}

Teroris merupakan suatu permasalahan yang sangat serius dan tidak bisa dipandangan dengan sebelah mata karena teroris merupakan sebuah ancaman bagi setiap warga Negara karena dapat menimbulkan bahaya ,ketidaknyamanan dunia dan bahkan karena perbuatan dari teroris ini sangat merugikan masyarakat. Teroris merupakan kejahatan yang sangat luar biasa dan mengancam banyak nyawa, maka dalam mengantisipasi adanya terror dari teroris di suatu daerah maka pemerintah juga harus ektra luar biasa dalam menanggapi dan meghadapi masalah teroris.

Di dalam negeri kita, tentunya hospitalitas kepemimpinan yang ditunjukkan pemerintah dapat dilihat dari bagaimana pergerakan yang dilakukan baik dari segi hukuman kepada pelaku teroris dan juga adanya kesiapan dari petugas yang berwenang seperti TNI dan POLRI.

Kata kunci : Hospitalitas,Teroris,Kepemimpinan,Pemerintah

\section{Pendahuluan}


Teroris secara umu berarti tindakan menakut-nakuti (to terrify), Namun, kata teroris dari Kamus Besar Bahasa Indonesia (KBBI) berarti orng yang menggunakan kekerasan ,sesuatu yang mengerihkan, atau kekejaman atau seseorang atau kelompok-kelompok tertentu membuat suasana takut. Teroris adalah orang ata tindakan kejahatan yang dilakukan untuk meneror atau membuat suasana dilingkungan hidup atau di sekitaran tempat yang ramai menjadi kacau. Tindakan ini bersifat keras dan membuat orang-orang terancam di mana terdapat suatu tempat yang strategis dapat terjadi kehancuran atau kerusakan. Teroris juga merupakan bentuk intimidasi kepada masyarakat dan pemerintah karena adanya pertentangan mengenai ideologi, keagamaan bahkan dapat ditimbulkan karena kesenjangan ekonomi.Dan terkadang faktor kepercayaan.Dalam menanggulangi adanya teroris yang berkeliaran dan mengancam masyarakat, maka dalam pemerintahan dibutuhkan orang-orang yang mempunyai jiwa kepemimpinan yang berkualitas,pantang menyerah dan bertanggung jawab. Wujud dari seorang pemimpin yang berkualitas dan bertanggung jawab dapat dilihat dari perbutan serta bagaimana mereka menerapkan hospitalitas.

Hospitalitas berarti adanya seseorang yang bermurah hati atau seseorang yang ramah $^{1}$,arti lain hospitalitas adalah bentuk praktek ialah dengan tidak pilih-pilih kasih atau membeda-bedakan ${ }^{2}$ Dikatakan bahwa seorang pemimpin mampu mempengaruhi seseorang atau kelompok dalam hal mencapai sasaran atau tujuan serta harus bisa memberikan memotivasi dan dorongan untuk kelompoknya, Begitupun halnya dalam hal mengantisipasi teroris sangat dibutuhkan sosok pemimpin yang mampu mengontrol keadaan dan mampu membuat suasana yang sebelumnya kacau karena ulah dari teroris menjadi lebih Damai dan tenang dengan cara memberikan perhatian kepada masyarakat serta memberikan rasa aman.Namun tidak menutup kemungkinan masyarakat juga akan kembali menyalahkan pemerintah serta petugas Apabila petugas Lalai dalam menjalankan tugasnyan,karena bisa kebobolan dalam mengamankan masyarakat dan Negara.

\section{Rumusan Masalah}

a.bagaiamana itu teroris.?

b.Penanggulangan pemerintah terhadap teroris.?

c. Hospitalitas dalam pemberantasan teroris.?

\footnotetext{
${ }^{1}$ Michele Hershberger, Hospitalitas Orang Asing: Teman Atau Ancaman, (Jakarta: BPK Gunung Mulia, 2009).

2 Daniel Fajar Panuntun dan Eunike Paramita, "Hospitalitas Kristen dan Tantangannya di Tengah Pandemi Covid19", Jurnal Multikultural dan Multireligius, Vol 19, No 1, (Oktober 2020), 72
} 


\section{Tujuan}

Tujuan dari penelitian ini ialah sebagai beriku :

1. supaya mengetahui mengenai bahaya terorisme yang beredar dikehidupan masyarakat

2. yaitu untuk mengetahui peran pemerintah dalam menanggulangi adanya terorisme yang ada.

3, yaitu untuk mengetahui pentingnya kepemimpinan dalam menerapkan hospitalitas untuk memperhatikan masyarakat dari bahaya

\section{Manfaat}

Dengan adanya penulisan ini diharapkan dapat menjadi inspirasi kepada pembaca bahwa kita harus serius menanggapi masalah teroris serta tetap waspada dan langkha-langkah yang harus ditempuh dalam menanggulangi teroris. tetapi, tidak hanya sekedar untuk dibaca tetapi menerapkan dan mengetahui bahwa dalam menjalini kehidupan perlu berhati-hatikarena adanya terror yang dapat terjadi kapan saja dan dimana saja terutama ditempat- tempat keramaian seperti pasar,gereja,tempat-tempat keramaian lainnya.

\section{Metode Penelitian}

Karya penulisan ini menggunakan penelitian pendekatan secara kuantitatif atau di mana analisis yang digunakan di dalamnya ialah dengan cara metode literature kepustakaan.

\section{Pembahasan}

Latar Belakang

Dunia zaman sekarang sudah sangat modern sehingga tindakan kejahatan juga tidak akan terhindarkan. Salah satu tindakan kejahatan yang luar biasa terjadi yang menjadi sorotan masyarakat dan dunia adalah teroris. Berbicara tentang teroris tidak lepas dari negara Indonesia di mana terjadi beberapa kasus terorisme setiap tahunnya. Tidak hanya di Indonesia tetapi kasus teroris juga terjadi di Negara-negara lain. Teroris pastinya tidaklah terdiri dari beberapa orang tetapi tidak bisa dipungkiri bahwa teroris ini memiliki kelompokkelompok dari suatu gabungan kelompok di tempat lain yang memiliki jejaring 
transnasional3. Orang-orang yang menjadi teroris adalah mereka yang berasal dari golongangolongan yang terdiskriminasi atau golongan minoritas dalam hal pergaulan atau mereka yang merasa diabaikan karena kurang mapan.

Teroris sangat sulit terdeteksi karena mereka memanfaatkan teknologi global yang ada dalam melancarkan aksinya seperti internet maupun telepon seluler yang akan sangat membantu dalam berkomunikasi dengan anggota kelompoknya. Hal inilah yang membuat pemerintah kesulitan dalam memberantas atau memutuskan rantai jaringan teroris. Upaya yang dilakukan pemerintah dalam memberantas teroris serta menanggulanginya sudah dapat kita rasakan namun masih banyak yang perlu dibenahi agar masyarakat merasakan adanya perhatian yang serius dari pemerintah sehingga masyarakat tidak merasakan terror dari oknum-oknum yang tidak bertanggungjawab dan menjalani kehidupan dengan damai tanpa adanya gangguan-ganguan yang mengancam nyawa.

\section{A. Teroris}

Kata teroris bukanlah kata yang jarang didengar di dunia zaman modern ini, dalam perkembangan teroris ini membuat dunia merasa tidak aman karena tidak ada yang bisa mennentukan dan memastikan kapan dan dimana para teroris akan beraksi. Oleh sebab itu, PM Howard menerbitkan kebijakan Travel Warning bagi Negara yang rentan terhadap serangan teroris. Teroris dengan leluasa berpindah dari Negara ke Negara lain dikarena adanya beberapa Negara yang membantu dan menyediakan fasilitas serta memberikan perlindungan kepada para teroris, seperti memberikan dana pembiayaan yaitu bantuan senjata dan juga bantuan untuk pemalsuan passpor. Hal inilah yang membuat para teroris dengan mudahnya melancarkan aksi terror dan kekerasan di berbagai tempat yang membuat para aparat kesusahan dalam menelusuri jejak teroris.

Teroris juga menjadi suatu aliran kepercayaan dalam hal memaksakan kehendak melalui tindakan illegal, hal inilah yang menjerumuskan kepada kekerasan dan bahkan kepada pembunuhan. Tindakan yang dilakukan oleh kelompok-kelompok teroris bukanlah sesuatu yang dilakukan secara semena-mena namun mereka mempunyai kriteria yang terstruktur, terencana atau aksi teroris ini dilakukan oleh orang-orang yang berpengalaman dan professional. Teroris bertujuan untuk merubah dasar ideologi Negara dan agama sehingga mereka berusaha menciptakan rasa intimidasi atau ketakutan dan ketidakamanan

\footnotetext{
${ }^{3}$ Muhammad A.S. Hikam, 2016, Deradikalisasi: Peran Masyarakat Sipil Indonesia Membendung Radikalisme, Jakarta: PT Kompas Media Nusantara, Hal. 33-34.
} 
dalam masyarakat. Dengan demikian dapat dipahami bahwa para teroris ini tidak berpegang kepada hukum atau norma-norma yang berlaku

Menurut FX Adji Samekto yang mengutip pendapat James H. Wolfe, menyebutkan beberapa karakteristik terorisme, antara lain sebagai berikut :

a. Terorisme dapat didasarkan pada motivasi yang bersifat politis maupun non politis.

b. Sasaran yang menjadi objek aksi terorisme bisa sasaran sipil (supermarket, mall, sekolah, tempat ibadah, rumah sakit dan fasilitas umum lainnya), maupun sasaran non sipil (tangsi militer, kamp militer). c. Aksi terorisme dapat ditujukan untuk mengintimidasi atau mempengaruhi kebijakan pemerintah Negara.

d. Aksi terorisme dilakukan melalui tindakan yang tidak menghormati hukum internasional atau etika internasional. Serangan yang dilakukan dengan segaja untuk membinasakan penduduk sipil seperti yang terjadi pada Bom Bali beberapa waktu lalu adalah pelanggaran hukum internasional.

e. Aktivitas teroris menciptakan perasaan tidak aman dan merupakan gangguan psikologis untuk masyarakat.

f. Persiapan atau perencanaan aksi teror bisa bersifat multinasional. Maksudnya, pelaku terorisme dapat dilakukan oleh warga negara itu sendiri maupun oleh warga nagara asing atau gabungan dari keduanya.

g. Tujuan jangka pendek aksi terorisme adalah menarik perhatian media massa dan perhatian publik.

h. Aktivitas terorisme mempunyai nilai mengagetkan (shock value) yang bagi teroris bergguna untuk mendapatkan perhatian. Untuk itulah dampak aktivitas terorisme selalu terkesan kejam, sadis dan tanpa menghargai nilai-nilai kemanusiaan ${ }^{4}$

Dalam melancarkan aksinya, ada suatu hal yang melatar belakangi aksi teroris seperti motivasi serta pemikiran yang rasional, motivasi dari keadaan psikologis dan motivasi dari kebudayaan. Selain dari pada karateristik dan motivasi, maka perlu juga memahami tipologi teroris karena hal ini kita dapat mengetahui tujuan dari teroris.

\footnotetext{
${ }^{4}$ Dikutip dari FX Adji Samekto, di dalam tulisannya yang dimuat di Suara Merdeka, tanggal 24 Oktober 2012, http://www.suaramerdeka.com/harian/0210/24/kha1.htm, diakses tanggal 17 April 2021
} 


\section{B. Penanggulangan Pemerintah terhadap Teroris}

Aksi teroris merupakan suatu tindakan kriminal dimana kegiatan ini sangat meresahkan serta membahayakan kehidupan warga Negara. Pandangan tersebut disampaikan dengan alasan untuk memberantas para teroris dengan cara mengungkapkan masalah-masalah dari teroris. Upaya yang terus dilakukan oleh pemerintah dalam memberantas jaringan teroris maka pemerintah tetap berpegang kepada prinsip yang dilakukan sebelumnya yaitu prevensif, Preemtif dan represif.

Upaya prevensif; yaitu upaya dalam mengantisipasi terjadinya kejahatan Upaya penal yang dilakukan dalam mengantisipasi kejahatan terkadang mengalami keterbatasan maka ada upaya non-penal yang merupakan cara untuk mencegah terjadinya kejahatan maka upaya ini dikenal sebagai prevensif.

Langkah-langkah preventif yang diambil pemerintah dalam menanggulangi tindak pidana terorisme ialah :
a. meningkatkan keamanan terhadap senjata api
b. meningkatkan keamanan terhadap transportasi
c. meningkatkan keamanan terhadap sarana public
d. meningkatkan keamanan terhadap sistem komunikasi
e. meningkatkan keamanan terhadap kepentingan asing dan fasilitas diplomatic
f. meningkatkan keamanan terhadap kesigapan dalam menghadapi seangan teroris
g. meningkatkan keamanan terhadap fasilitas internasional
h. meningkatkan keamanan terhadap bahan-bahan kimia yang rentan dipakai untuk merakit bom

i. meningkatkan keamanan terhadap dokumen-dokumen keluar masuk Negara seperti passport

j. meningkatkan keamanan terhadap kegiatan masyarakat

2. Upaya preemtif yaitu upaya yang dilakukan oleh pemerintah untuk mencegah atau memberantas kejahatan dengan cara menegakkan hukum 
Upaya preemtif yang dapat dilakukan yaitu :

a. Mengenai kepercayaan atau agama, arti lain memberikan pencerahan agama menurut kepercayaan masing-masing

b. Mampu menyesuaikan kebijakan politik

c. Ditetapkan hukuman mati kepada pelaku teroris

\section{Hospitalitas dalam Pemberantasan Teroris}

Hospitalitas secara etimologi dalam bahasa Yunani yaitu philoxenia dapat diartikan secara umum; kasih kepada orang asing. Kata hostis berasal dari bahasa Sanskritghas yaitu makan sedangkan hospes berarti dia yang sebagai penghibur atau melayani orang asing atau tuan rumah ${ }^{5}$ Dengan demikian, hospitalitas adalah proses dari merubah orang asing menjadi tuan rumah. Sedangkan hospitalitas dalam kehidupan sehari-hari biasa disebutkan orang-orang sebagai perbuatan yang baik. Hospitalitas kepemimpinan dalam pemerintah dalam menanggulangi terorisme dapat dilihat dari bagaimana upaya yang dilakukan untuk mengantisipasi adanya aksi terorisme disuatu daerah. Upaya-upaya lainnya yaitu :

1. Penegakan hukum Penyelenggararan penegakan hukum tentang tindakan terorisme diatur dalam UU No. 15 tahun 2003 yang menetapkan Perpu No. 1 tahun 2002 tentang pemberantasan tindak pidana terorisme sebagai UU.

2. Pembentukan Badan Nasional Penanggulangan Terorisme (BNPT) BNPT dibentuk melalui Peraturan Presiden Nomor 46 tahun 2010, yang berubah menjadi Peraturan Presiden Nomor 12 tahun 2012.

3. Pelibatan TNI dan Polri Pelibatan TNI dan Polri dala upaya pemberantasan Terorisme diatur dalam UU No. 34 tahun 2004.

\footnotetext{
${ }^{5}$ Panu Minkkinen, Hostility and Hospitality, diakses dari www.helsinki.fi/nofo/NoFo4Minkkinen.pdf, tanggal 18 April 2021
} 
4. Deradikalisasi Deradikasi adalah sebuah strategi kontra terorisme untuk merubah idiologi kelompok terori. Cara ini dilakukan untuk menjauhkan mereka dari kelompok radikal tempat mereka berlindung ${ }^{6}$

\section{Kesimpulan}

Hospitalitas berarti adanya seseorang yang bermurah hati atau seseorang yang ramah ,arti lain hospitalitas adalah bentuk praktek ialah dengan tidak pilih-pilih kasih atau membeda-bedakan Dikatakan bahwa seorang pemimpin mampu mempengaruhi seseorang atau kelompok dalam hal mencapai sasaran atau tujuan serta harus bisa memberikan memotivasi dan dorongan untuk kelompoknya, Begitupun halnya dalam hal mengantisipasi teroris sangat dibutuhkan sosok pemimpin yang mampu mengontrol keadaan dan mampu membuat suasana yang sebelumnya kacau karena ulah dari teroris menjadi lebih Damai dan tenang dengan cara memberikan perhatian kepada masyarakat serta memberikan rasa aman.Namun tidak menutup kemungkinan masyarakat juga akan kembali menyalahkan pemerintah serta petugas Apabila petugas Lalai dalam menjalankan tugasnyan,karena bisa kebobolan dalam mengamankan masyarakat dan Negara.

\section{Saran}

Dalam menyusun karya tulisan ini,pasti tidak luput dari kesalahan,karena itu sangat diharapkan untuk memberikan kritikan dan masakukan yang dapat mengengembangkan tulisan ini.

\footnotetext{
${ }^{6}$ Reni Windiani, Peran Indonesia Dalam Memerangi Terorisme, Jurnal Ilmu Sosial, Vol. 16, No. 2, Juli 2017, hlm 139-140
} 


\section{Referensi}

Hershberger, Michele. Hospitalitas Orang Asing: Teman Atau Ancaman. Jakarta: BPK Gunung Mulia, 2009.

Muhammad A.S. Hikam, 2016, Deradikalisasi: Peran Masyarakat Sipil Indonesia Membendung Radikalisme, Jakarta: PT Kompas Media Nusantara

Panuntun, Daniel Fajar dan Eunike Paramita. "Hospitalitas Kristen dan Tantangannya di Tengah Pandemi Covid-19", Jurnal Multikultural dan Multireligius, Vol 19, No 1, (Oktober 2020),

Affrair, Foreign and Trade. Consular Service-Travel Advice Indonesia

Adjie, M. Sc. Terorisme, Jakarta: Sinar Harapan

Alexander, Yohah and Seymour Maxwell Flinger, Terrorism Interdisciplenary Prespectives, New York: The Jay Press, 1997

Samekto,Adji. "SuaraMerdeka" , http://www.suaramerdeka.com/harian/0210/24/kha1.htm, (diakses 17 April 2021)

Firmansyah, Hery. "Upaya Penanggulangan Tindak Pidana Terorisme di Indonesia", Jurnal MIMBAR HUKUM, Vol. 23, No. 2, (Juni 2011)

Windiani, Reni. Peran Indonesia Dalam Memerangi Terorisme, Jurnal Ilmu Sosial, Vol. 16, No. 2, (Juli 2017) 